\title{
DYNAMIC AND STATIC MECHANICAL PROPERTIES OF Eucalvp- tus nitens THERMALLY MODIFIED IN AN OPEN AND CLOSED REACTOR SYSTEM
}

\author{
Maximilian Wentzel ${ }^{1, \diamond}$, Christian Brischke ${ }^{1}$, Holger Militz ${ }^{1}$
}

\begin{abstract}
Eucalyptus nitens is a fast growing plantation species that has a good acclimation in Chile. It is commonly used for pulp and paper, but there is a growing market for solid wood products made from this species and an interest on producing high quality material. Thermal modification technology have been used to obtain high quality product out of fast growing plantation species. In this study we modified Eucalyptus nitens to analyse the influences of the process conditions and evaluated its mechanical properties under several process conditions. The material was modified in a closed system under elevated pressure and controlled relative humidity (30 and $100 \%$ relative humidity) at temperatures between 150 and $170^{\circ} \mathrm{C}$, and in an open system with a standard thermal modification procedure between 160 and $230^{\circ} \mathrm{C}$. Modulus of elasticity, modulus of rupture, deflection and work in bending (in elastic and inelastic proportions) and the resistance to impact milling in high energy multiple impact tests were determined. Mass loss after each modification was also measured and correlated with the mechanical properties. Anatomical properties of selected modifications were analysed. There were no significant differences between open and closed system modifications in both mechanical and anatomical properties.
\end{abstract}

Keywords: Bending, deflection, high energy multiple impact test, modulus of elasticity, modulus of rupture, wood anatomy.

\section{INTRODUCTION}

Currently, Eucalyptus nitens plantation wood is mostly used for pulp and paper or biofuels, but there is an interest to widen the use of this fast growing tree species in Chile. Thermal modification technologies show potential to produce high quality material and open new markets for the use of this species. These processes use treatment temperatures between $150^{\circ} \mathrm{C}$ and $240^{\circ} \mathrm{C}$ under different operating conditions, either steam, vacuum, nitrogen that limit the presence of oxygen in the process (Hill 2006, Militz and Altgen 2014). They can be separated in open systems, in which the modification happens at atmospheric pressure (ThermoWood (Mayes and Oksanen 2002), and closed systems, where the processes work under steam pressure, such as FirmoLin (Willems 2009) and WTT (Dagbro et al. 2010), or vacuum (TERMOVUOTO (Allegretti et al. 2012)), to name a few examples. The wood composition changes when it is exposed to high temperatures, and as a consequence, it improves the biological durability (Boonstra et al. 2007, Hakkou et al. 2006), and its dimensional stability (Boonstra and Tjeerdsma 2006, Tjeerdsma and Militz 2005), changing its mechanical properties (Esteves and Pereira 2009, Kubojima et al. 2000). These variations are closely related to the species and the process conditions. The static modulus of rupture (MOR) and the modulus of elasticity (MOE) are affected differently, as the MOR tends to decrease more than the MOE, as shown for thermal modifications of Betula papyrifera (Canadian white birch) (Poncsák et al. 2006) and Fagus sylvatica (European beech) (Tjeerdsma et al. 1998). In both species, MOE and MOR reduced with rising modification temperature. However, other authors showed that MOE of thermally modified wood can de higher than the reference values increased in certain thermal modifications (Borrega and Kärenlampi 2008, Kubojima et al. 2000, Lekounougou et al. 2011, Rautkari and 
Hill 2014, Santos 2000). The structural integrity of wood is also affected by the thermal modification, as the degradation of hemicelluloses (Alen et al. 2002, Boonstra and Tjeerdsma 2006, Sundqvist et al. 2006) can cause an increased brittleness of the material (Phuong et al. 2007, Weigl et al. 2012). This also contributes to the decomposition of cell wall components, which are related to the mass loss, causing defects in the microscopic structure of the wood, such as cracking and cell wall collapse (Awoyemi and Jones 2011, Biziks et al. 2013, Boonstra et al. 2006a, Boonstra et al. 2006b). These structural defects may contribute to the mechanical changes of the thermally modified wood.

To quantitatively analyze the structural changes, a method was developed to determine the structural integrity of wood in relation of its resistance to impact milling (RIM). This is determined in a High-Energy Multiple Impact (HEMI) mill, which had been designed using steel balls of different size in a heavy vibratory mill for crushing wood samples. The process was developed to overcome the drawbacks of standard dynamic strength tests. Instead of using a high number of replicate wood specimens, the number of events that affect directly the wood can be multiplied (Brischke 2017, Brischke et al. 2006a).

The objective of this study was to examine the static mechanical behavior (MOE and MOR) and the dynamic mechanical behavior (HEMI test) of eucalypt wood after treatments in both open and closed reactor systems with the goal to analyze the influence of the process conditions. Selected samples from the open and closed modification systems were chosen to be analyzed with a scanning electron microscope (SEM) to reveal possible differences in the anatomical structure that could be influential in the changes of the mechanical properties.

\section{MATERIAL AND METHODS}

E. nitens wood that came from 19 year old plantations of the región Bío-Bío in Chile was used. Wood specimens with dimensions of $20 \times 50 \times 650 \mathrm{~mm}^{3}$ (radial x tangential x longitudinal) were prepared from kilndried wood that had an average moisture content (MC) of 12\% avoiding knots and other visible flaws. For each modification process ten specimens were used.

\section{Thermal modification process}

Thermal modifications in an open and a closed systems were performed. The open system was a process similar to the Thermowood procedure (Mayes and Oksanen 2002), in which the first step is a pre-drying that starts at $100^{\circ} \mathrm{C}$ up to $130^{\circ} \mathrm{C}$ at a heating rate of $2^{\circ} \mathrm{C}$ per hour. Afterwards the temperature ramps up at $12^{\circ} \mathrm{C}$ per hour to the peak temperature, where it is hold up for 3 hours. Finally, the temperature decreased at a rate of $20^{\circ} \mathrm{C}$ per hour to $65^{\circ} \mathrm{C}$. In the case of the closed system modification, the WTT process (Willems 2009) was used. It consist of four steps: a 50 min holding step at pre-vacuum at $<14 \mathrm{kPa}$, temperature increase in a rate of $12^{\circ} \mathrm{C}$ per hour until modification temperature, a holding step at the peak temperature for 3 hours and a temperature decrease in a rate of $20^{\circ} \mathrm{C}$ per hour up to $65^{\circ} \mathrm{C}$. The total duration of the process was shorter in the closed system than in the open system. The list of modifications is presented in Table 1. Both processes were performed in a laboratory scale reactor in a stainless steel vessel with electric heating cables to heat up and cooling coils to cool down after the process. Exhaust valves were used to release the excess pressure. A gas washer was used to condense the volatiles produced by the modification. Water vapour was produced by heating an external water reservoir connected to the vessel. When using the equipment for closed system modifications, a pre-vacuum was applied $(13 \mathrm{kPa})$, with the water vapour pressure being adjusted by heating the water reservoir and discharging the excess pressure to maintain the relative humidity (RH) constant. A scheme is presented in Figure 1. 


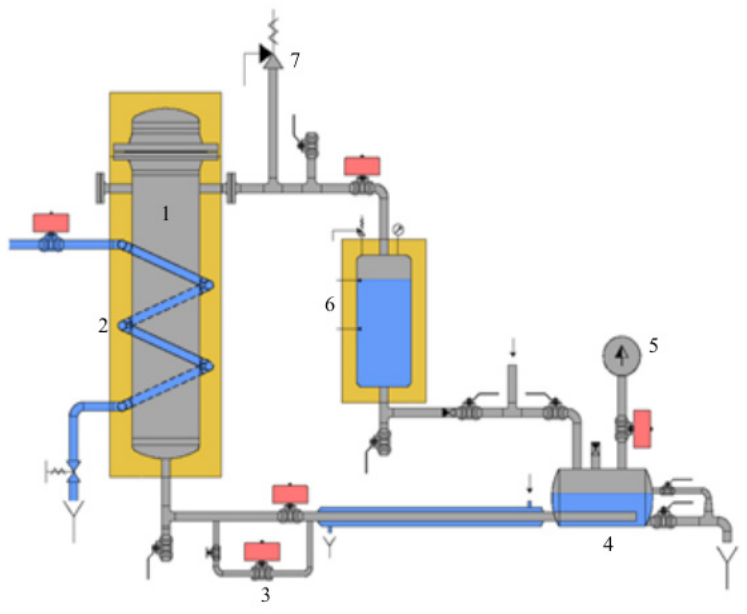

Figure 1: Scheme of the laboratory scale reactor. 1: Vessel for the wood specimens. 2:Cooling coil to regulate temperature inside the vessel. 3: Exhaust valves to regulate pressure. 4: Gas washer. 5: Vacuum pump. 6: Steam generator. 7: Safety valve. Adapted from Willems (2009).

Table 1: Peak temperature, maximum pressure, extractive content, corrected mass loss (CML), moisture content (MC) and total process duration (TPD) of both modifications (open and closed) and the relative humidity (RH) applied in the thermal modifications in the closed systems. Duration of the modification at peak temperature was 3 hours for all processes.

\begin{tabular}{|c|c|c|c|c|c|c|}
\hline \multicolumn{7}{|c|}{ Open System } \\
\hline $\begin{array}{c}\text { Peak } \\
\text { temperature } \\
\left({ }^{\circ} \mathrm{C}\right) \\
\end{array}$ & $\begin{array}{c}\text { Max } \\
\text { pressure } \\
\text { (mPa) }\end{array}$ & $\begin{array}{l}\text { RH } \\
(\%)\end{array}$ & $\begin{array}{c}\text { Extractives } \\
(\%)\end{array}$ & $\begin{array}{c}\text { CAIL } \\
(\%)\end{array}$ & $\begin{array}{l}\text { Final } \\
\text { MC } \\
(\%) \\
\end{array}$ & $\begin{array}{c}\text { TPD } \\
\text { (h) }\end{array}$ \\
\hline 160 & atmospheric & - & 6,76 & 5,37 & 3,34 & 30 \\
\hline 180 & atmospheric & . & 9.04 & 7,89 & 2,04 & 33 \\
\hline 200 & atmospheric & - & 12,29 & 14,61 & 2,04 & 35,5 \\
\hline 210 & atmospheric & - & 12,70 & 18,68 & 2,18 & 37 \\
\hline 220 & atmospheric & . & 9,12 & 16,78 & 2.25 & 38 \\
\hline 230 & atmospheric & - & 7,44 & 19,29 & 2,44 & 39,5 \\
\hline \multicolumn{7}{|c|}{ Closed System } \\
\hline $\begin{array}{c}\text { Peak } \\
\text { temperature } \\
\left({ }^{\circ} \mathrm{C}\right)\end{array}$ & $\begin{array}{c}\text { Max } \\
\text { pressure } \\
(\mathrm{mPa})\end{array}$ & $\begin{array}{l}\text { RH } \\
(\%)\end{array}$ & $\begin{array}{c}\text { Extractives } \\
(\%)\end{array}$ & $\begin{array}{c}\text { CMIL } \\
(\%)\end{array}$ & $\begin{array}{l}\text { Final } \\
\text { MC } \\
(\%)\end{array}$ & $\begin{array}{l}\text { TPD } \\
\text { (h) }\end{array}$ \\
\hline 150 & 0,14 & 30 & 5,96 & 2,55 & 4,50 & 16,5 \\
\hline 160 & 0,18 & 30 & 7,64 & 4,99 & 3,85 & 18 \\
\hline 170 & 0,23 & 30 & 8,41 & 6,29 & 3,20 & 19 \\
\hline 150 & 0.47 & 100 & 12,72 & 11,36 & 5.27 & 16,5 \\
\hline 160 & 0,61 & 100 & 13,16 & 18,57 & 4,94 & 18 \\
\hline 170 & 0,77 & 100 & 10,05 & 20,51 & 4,62 & 19 \\
\hline
\end{tabular}

The final wood MC was measured after each modification by difference of dry weight using small pieces collected from each specimen, so that this value could be extracted from the dry weight of each specimen. The degradation products of the cell wall carbohydrates accumulate in the wood during modifications at high temperatures (Altgen et al. 2016). Hence, for a correct measurement of mass loss, the extractive content was measured as described by the Solvent Extractives of Wood and Pulp Test Method T $204 \mathrm{~cm}-07$ (TAPPI 1997) using a Soxhlet apparatus. The corrected mass loss (CML) was calculated based on the dry and extractive-free weight of the wood before (unmodified) and after each process following Equation 1 and Equation 2. It should be noted that the wood specimens were neither dried nor extracted prior to each modification process.

$$
O D_{E}=O D-\left(O D^{*} E C / 100\right)
$$


where OD is the oven dry weight of small wood specimens in grams, EC is the extractive content and $\mathrm{OD}_{\mathrm{E}}$ is the oven dry and extractive free weight of the specimen. Now the CML can be calculated using Equation 2

$$
C M L=\left(O D_{E B}-O D_{E A}\right) * 100 / O D_{E B}
$$

where $\mathrm{OD}_{\mathrm{EB}}$ is the oven dry and extractive free weight of the specimen before the modification process in grams and $\mathrm{OD}_{\mathrm{EA}}$ is the oven dry and extractive free weight of the specimen after the modification process in grams.

The increase of the extractive content is related to the generation of degradation products that outweighed their vaporization. By increasing the temperature beyond $210^{\circ} \mathrm{C}$ it seems that the vaporization of the degradation products increases more than the generation of them (Wentzel et al. 2008a). Thus there is a decrease in the $\mathrm{CML}$ at $220^{\circ} \mathrm{C}$ because the extractive content was less than at $210^{\circ} \mathrm{C}$ in the open system.

\section{Mechanical properties}

A three-point bending test according to DIN 52186 (1978) was conducted using a universal testing machine (Zwick Roell Z010, Zwick, Ulm, Germany) to measure the modulus of elasticity (MOE) and the modulus of rupture (MOR) (both in $\mathrm{Nmm}^{-2}$ ) on wood specimens of $10 \times 10 \times 180 \mathrm{~mm}^{3}$ (radial $\times$ tangential $\times$ longitudinal) that were conditioned at $20^{\circ} \mathrm{C} / 65 \% \mathrm{RH}$ before the test. At least 15 replicates per modification were tested. The span length of the samples was $150 \mathrm{~mm}$ and the load was applied in the transversal direction with the testing speed adjusted individually for each modification to allow failure of the samples within $90 \pm 30 \mathrm{~s}$. A load decrease of $10 \%$ or more of the maximum load was defined as failure. Deflection and work in bending were measured using the formulas presented by Altgen and Militz (2016). The elastic deflection was divided into elastic $\left(\delta_{\mathrm{e}}\right)$ and inelastic deflection $\left(\delta_{\mathrm{i}}\right)(\mathrm{mm})$ using the Equation 3 that is represented in Figure 2,

$$
\delta \mathrm{e}=P_{\max } * \delta / P
$$

where $\mathrm{P}_{\max }$ is the maximum load $(\mathrm{N}), \mathrm{P}$ represents any load $(\mathrm{N})$ below the proportional limit and $\delta$ is the deflection $(\mathrm{mm})$ at the respective load $\mathrm{P}$. The inelastic deflection $\left(\delta_{\mathrm{i}}\right)$ was calculated by subtracting the elastic deflection from the deflection at the maximum load. Work in bending $\left(\mathrm{W}_{\max }\right)(\mathrm{Nmm})$ was calculated as the area under the load deflection curve using Equation 4,

$$
W_{\max }=\int_{0}^{\delta_{\max }} P d \delta
$$

Work in bending was separated into inelastic and elastic proportions $\left(\mathrm{W}_{\mathrm{e}}(\mathrm{N} \mathrm{mm})\right.$ and $\mathrm{W}_{\mathrm{i}}(\mathrm{N} \mathrm{mm})$ respectively) as seen in Figure 2. The elastic proportion was calculated using Equation 5,

$$
W_{e}=\left(\ddot{\mathrm{a}}_{e} / 2\right) * P_{\max }
$$

The inelastic work in bending $\left(\mathrm{W}_{\mathrm{i}}\right)$ was calculated by subtracting the elastic deflection from the deflection at the maximum load. All results are presented as a ratio with the average value of the reference set to 1 . 


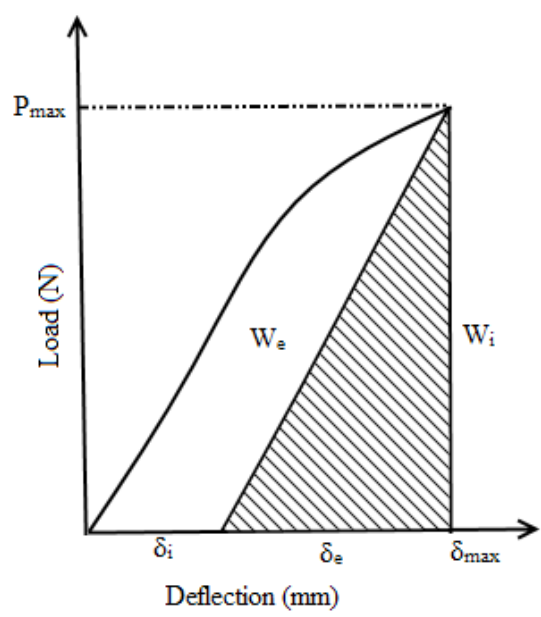

Figure 2: The schematic load-deflection curve of the three-point bending test. Maximum load $\left(\mathrm{P}_{\max }\right)$, deflection at maximum load $\left(\delta_{\max }\right)$, elastic deflection $\left(\delta_{\mathrm{e}}\right)$, inelastic deflection $\left(\delta_{\mathrm{i}}\right)$, elastic work in bending $\left(\mathrm{W}_{\mathrm{e}}\right)$ and inelastic work in bending $\left(\mathrm{W}_{\mathrm{i}}\right)$. Adapted from Altgen and Militz (2016).

\section{High-energy multiple impact test (HEMI)}

The development of the HEMI test had been described by Rapp et al. (2006) and Brischke et al. (2006b). In the present study, the process was adapted from the procedure presented by Brischke (2017). 20 oven-dry specimens of $10 \times 10 \times 10 \mathrm{~mm}$ were placed into a bowl of $140 \mathrm{~mm}$ inner diameter of a heavy impact ball mill (Herzog HSM 100, Osnabrück, Germany), together with one steel ball of $35 \mathrm{~mm}$ diameter, three steel balls of $12 \mathrm{~mm}$ diameter, and three steel balls of $6 \mathrm{~mm}$ diameter. The bowl was shaken for $60 \mathrm{~s}$ with a rotary frequency of $23,3 \mathrm{~s}^{-1}$ and a stroke of $12 \mathrm{~mm}$. The fragments of the 20 specimens were fractionated on a slit sieve with a slit width of $1 \mathrm{~mm}$ using an orbital shaker at an amplitude of $25 \mathrm{~mm}$ and a rotary frequency of $350 \mathrm{~min}^{-1}$ for 2 min. The following values were calculated using Equation 6, Equation 7 and Equation 8:

$$
I=m_{20} / m_{\text {all }} * 100(\%)
$$

Where the degree of integrity (I) is the ratio of the mass of the 20 biggest fragments $\left(\mathrm{m}_{20}\right)$ to the mass of all fractions $\left(\mathrm{m}_{\text {all }}\right)$ after the crushing process.

$$
F=m_{<1 \mathrm{~mm}} / m_{\text {all }}
$$

Where the fine fraction $(\mathrm{F})$ is the ratio of the mass that is sieved and has a diameter of less than $1 \mathrm{~mm}$ $\left(\mathrm{m}_{<\mathrm{lmm}}\right)$, to the mass of all fractions $\left(\mathrm{m}_{\text {all }}\right)$ multiplied by 100 .

$$
R I M=(I-3 * F)+300 / 400(\%)
$$

Where RIM is the resistance to impact milling and represents the value of the measure for the structural integrity of the material. All results are presented as a ratio with the average value of the reference set to 1 . 


\section{Statistical evaluation}

Statistical analysis was performed to correlate selected chemical changes with mechanical properties using the Pearson Correlation Coefficient Test using the STATISTICA Software package Version 13.1 (StatSoft Inc., Tulsa, USA).

\section{Scanning electron microscopy}

For the scanning electron microscopy (SEM) a ZEISS EVO ILS 15 (Carl Zeiss Microscopy GmbH, Jena, Germany) was used. The specimens were taken from the wood before any mechanical test were performed. To obtain a smooth transversal surface, the samples were cut with a microtome knife. After mounting on an aluminum stub, the unmodified samples were carbon coated. Images were captured through detection of the secondary electrons. Working parameters were set to an accelerating voltage of $5 \mathrm{kV}$, a current of $40 \mathrm{pA}$, and a working distance of $8,5 \mathrm{~mm}$. The magnification used for imaging was 1000x. After taking the images, the samples were thermally modified. This was done to compare the differences before and after modification and to avoid some issues with the surface preparation, as the thermally treated samples tend to be brittle, making it difficult to obtain a smooth surface.

\section{RESULTS AND DISCUSSION}

\section{Static and dynamic mechanical properties}

The MOR ratio did not decrease at CML below 10\% (Figure 3a). At CML above 10\% the MOR ratio decreased up to 0,71 at $170^{\circ} \mathrm{C}$ and $100 \% \mathrm{RH}$, while at $230^{\circ} \mathrm{C}$ in the open system modification showed the highest decrease in the ratio $(0,74)$. The loss of MOR at the higher temperatures, in both open and closed systems, can be related to the degradation of hemicelluloses (Zaman et al. 2000). This was confirmed by Wentzel et al. (2018b), where the degradation of xylans was closely related to the decrease of MOR. The degradation was higher in the closed system modifications due to the high concentrations of acids that build up because of the pressure, meaning that even at lower temperatures, closed system modifications can cause an increasing degradation of the hemicelluloses than high temperature modifications in the open system. This removal of hemicelluloses leads to distribution of stress over less cell wall material (related to CML) as one of its functions is to serve as stress transfer between lignin and reinforcing the cellulose microfibrils in the wood cell wall (Winandy and Lebow 2001). A decrease in the equilibrium moisture content (EMC) caused by the thermal modification may also play an important role in the decrease of MOR. Borrega and Kärenlampi (2008) concluded that the mechanical properties were not only dependent of the mass loss, but also the relative humidity in the heating atmosphere, which influences the EMC of the wood after modification. In their study, MOR showed less decrease in modifications with lower EMC. In the case of the modified E. nitens, the EMC were shown to be lower in the open modification process (Wentzel et al. 2018a), which can be related to the slightly higher ratios presented in Figure 3a.

The MOE ratio decreases (Figure 3a) when the CML was above 10\% for both open and closed systems, although is less affected by the thermal modification than the MOR ratio. In the closed system the decrease in MOE is directly correlated to the CML, but in the open system modification there was an increase of the MOE ratio until $200^{\circ} \mathrm{C}$ reaching $1,2(\mathrm{CML} 15 \%)$, after that point it started to decrease but without showing a direct relation between the CML and the MOE. Similar peaks of MOE have been reported in other species, such as Canadian white birch (Lekounougou et al. 2011), Picea abies (Norway spruce) (Borrega and Kärenlampi 2008) and other eucalypt species, such as E. grandis and E. regnans (de Cademartori et al. 2015), and E. globulus (Santos 2000), although no type of treatment was mentioned in the latter.

The elastic deflection (Figure 3b) decreased with increasing CML in all the closed system modifications, while in the open system modification it was at its lowest at $200^{\circ} \mathrm{C}(0,72)$ and showed almost no variation in all other temperatures. On the other hand, the inelastic deflection was more sensitive to the thermal modification as it decreased further than the elastic deflection as the temperature rose on all the closed system modifications. The open system modifications showed a lower inelastic deflection ratio than in the closed system (Figure $3 b$ ), with its lowest peak being at $200^{\circ} \mathrm{C}(0,25)$. This could be related to an ultra-structural realignment that could cause to reduce the capabilities of the cell wall components for plastic flow (Altgen and Militz 2016). The results were similar to what was obtained for European beech (Altgen and Militz 2016) and Norway spruce (Borrega and Kärenlampi 2008) in treatments in dry conditions. 

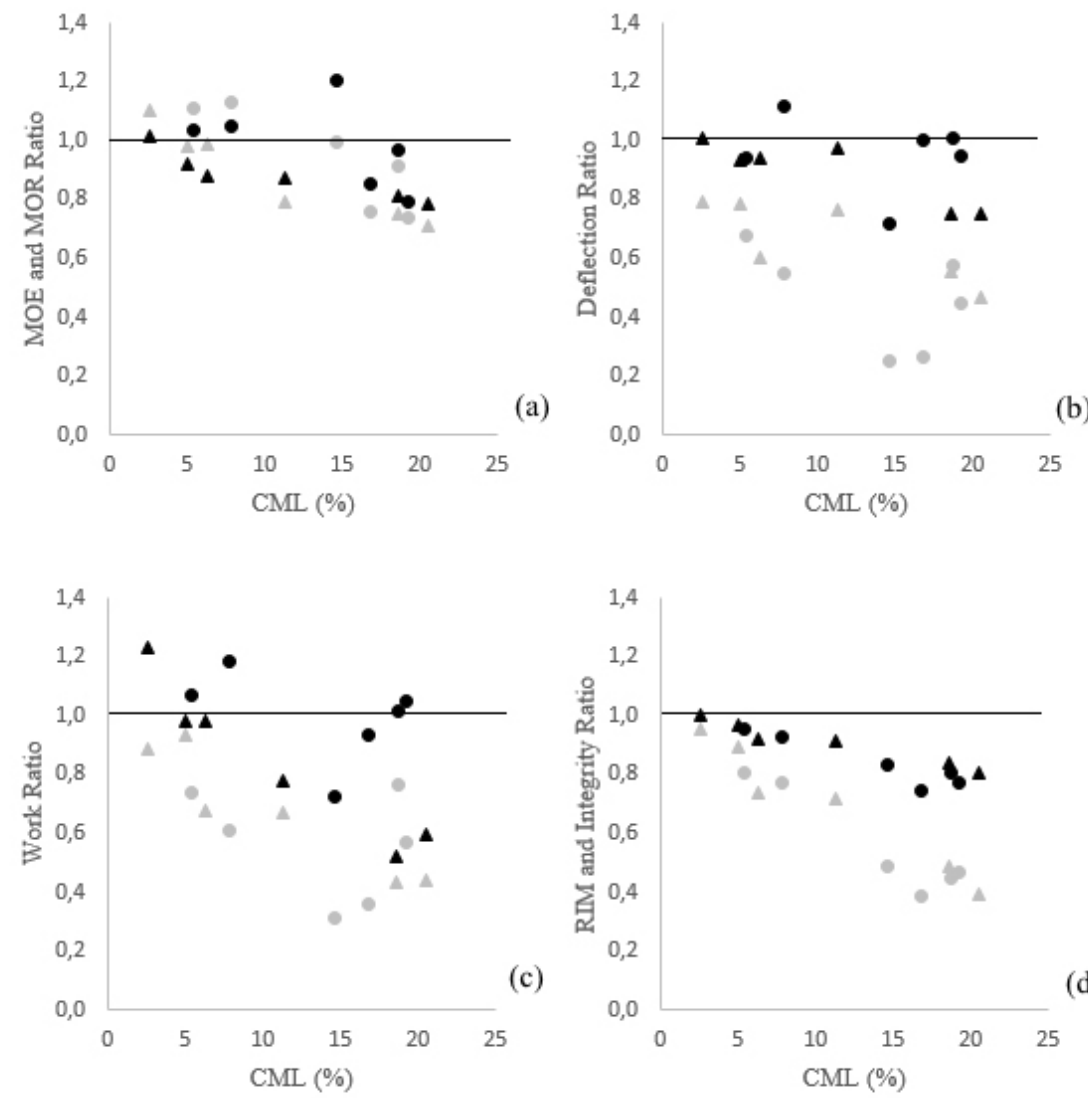

(d)

Figure 3: Ratio of MOE, MOR (a), inelastic and elastic deflection (b) and work (c) (N=15), RIM and integrity (d) $(\mathrm{N}=20)$ as a function of CML. Circles represent open system modifications, triangles represent closed system modifications. Black represents MOE, elastic deflection, elastic work and RIM; grey represents MOR, inelastic deflection, inelastic work and degree of integrity. The line shows the unmodified reference value.

Elastic work ratio was higher at the lowest CML and then it decreased as the temperature rose in the closed system modifications at 30\% and $100 \%$ RH. At the open system it slightly increased at the lowest CML, reaching its lowest point at $200^{\circ} \mathrm{C}(0,73)$. As for the closed system, it showed similar tendencies as the deflection, but with slightly higher ratios. At higher CML the elastic work showed no variation in relation to the reference sample. The inelastic work had a similar tendency as the elastic work in all the closed system modifications, meanwhile the closed system had its lowest ratio at $200^{\circ} \mathrm{C}(0,31)$ (Figure $3 \mathrm{c}$ ). The changes could be associated to the inelastic deflection, as it influences the plastic flow, thus influencing negatively the work in bending (Altgen and Militz 2016).

There was a minor difference between open and closed modification systems in relation to the RIM and the degree of integrity. The slight differences between the modifications could be related to changes at a cell wall level, since the RIM is directly correlated with the decrease in microstructural integrity caused by heat-induced modification of the cell walls (Welzbacher et al. 2011). Both properties reduced when the temperature increased during the closed system modifications (Figure 3d). This reduction is in line with previous results (Brischke et al. 2006a, Rapp et al. 2006, Welzbacher et al. 2007, Welzbacher et al. 2011) confirming the strong correlation between RIM and the decrease in mass by heat treatment. On the other hand, in the open system the reduction of the RIM and the degree of integrity occurred until a CML of about $16,8 \%$ (modification at $220^{\circ} \mathrm{C}$ ) and then it slightly increased at $18,7 \%$ (modification at $210^{\circ} \mathrm{C}$ ). $\mathrm{CML}$ is related to the amount of extractive content, which also considers part of the degradation products caused by the thermal modification, deducted from the oven dry mass for its measurement, a higher degradation would mean a lower CML. When the E. nitens wood was modified over $210^{\circ} \mathrm{C}$, its relative content decreased (Wentzel et al. 2018b). As the RIM in the open 
system did not decrease linearly as the CML increased, it could mean that other chemical changes also could have influenced the RIM and should be taken into consideration when evaluating the results.

The correlations presented in Table 2 show that for the closed system significant positive correlations can be found between the dynamic (RIM and degree of integrity) and static (MOE, MOR) mechanical properties, which means that when one property increases or decreases, the other does too. The CML had also a significant negative correlation with the mechanical properties, as it increases when the mechanical properties decrease, confirming what was shown in Figure 3. Open system modification shows that MOE does not correlate with the other mechanical properties or the CML, whereas all the other properties correlate the same way as the closed system modification.

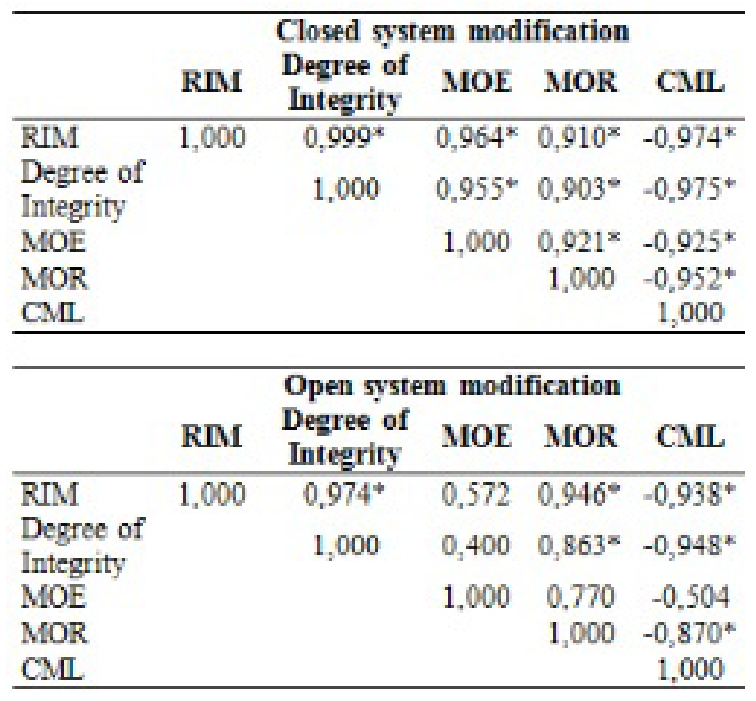

Table 2: Pearson correlation coefficients for RIM, degree if integrity, MOE, MOR and CML in open and closed system modification. Significant correlations $(p<0,05)$ were marked with an asterisk $(*)$.

When directly comparing two processes with similar CML from the open and closed system, the process at $160^{\circ} \mathrm{C}$ and $100 \% \mathrm{RH}$ and the process at $210^{\circ} \mathrm{C}$ had similar values $(18,57 \%$ and $18,68 \%$ respectively), there were some slight differences in all the ratios of their respective static mechanical properties (closed system presented lower values), but similar values in the dynamic mechanical properties.

\section{Scanning electron microscopy}

For this study, we focused on the development of cracks due to thermal modification. Previous studies show that there are no changes in the structure of ray parenchyma, vessels and fibers tissues before and after modification, as shown in E. grandis thermally modified up to $180^{\circ} \mathrm{C}$ (Batista et al. 2015) and birch and beech in a two-stage thermal treatment (Boonstra et al. 2006b). The same authors (Boonstra et al. 2006b) showed that radial cracks and broken cell walls perpendicular to the fiber direction resulted in cracks that could lead to different failures in the mechanical tests. This was corroborated by Biziks et al. (2013), where voids and cracks were found on thermally treated birch. Figure 4 shows an unmodified E. nitens specimen. The wood cell walls of the fibers were all united by their respective middle lamellas (black arrows) and some of the pit connection between fibers can also be seen (white arrows). Figure 5 shows E. nitens thermally modified at $160^{\circ} \mathrm{C}$ and $100 \% \mathrm{RH}$ in a closed system and Figure 6 shows a specimen modified at $210^{\circ} \mathrm{C}$ in an open system. Both samples have the same CML (Table 1). It can be seen for both modifications, that the structure of the wood cell started to separate where the middle lamella was (black arrow in Figure 5 and Figure 6) and cracks started to spread to the surrounding cells. Cracks also start to develop where pit connections where exposed (white arrows in Figure 5 and Figure 6), which could be related to pit deaspiration, as described by Awoyemi and Jones (2011). Both crack developments happened in open and closed modifications, making it difficult to be certain that the process affects the wood structure differently. As with the mechanical properties, anatomical 
changes did not show significant differences between open and closed system modifications.

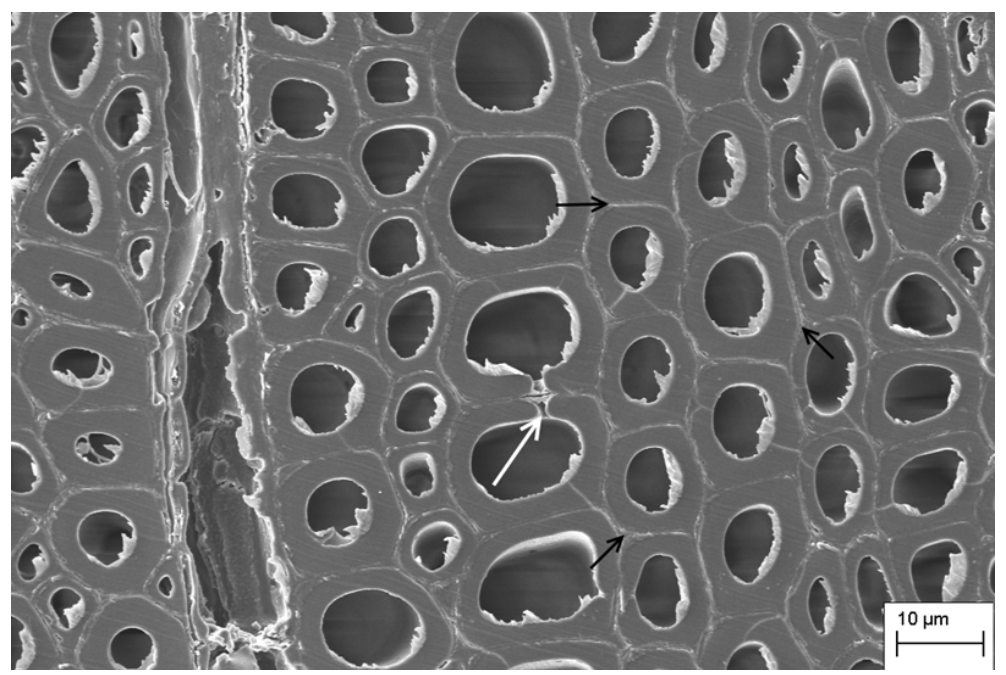

Figure 4: SEM image of unmodified specimen of E. nitens in the transversal direction. White arrow: Pit conection between wood cell wall of the fibers. Black arrows: Middle lamella.
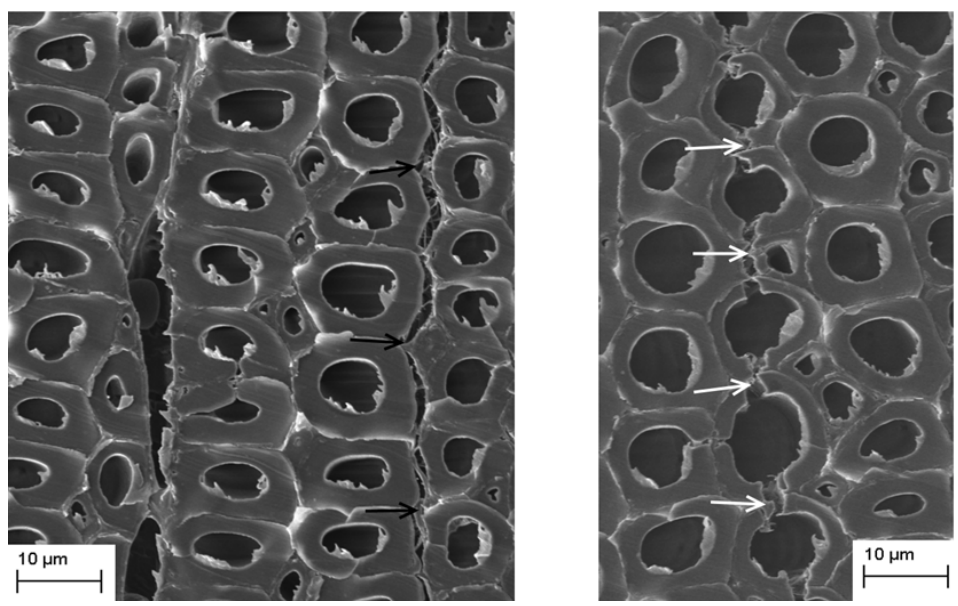

Figure 5: SEM images of thermally modified speciemens at $160^{\circ} \mathrm{C} 100 \% \mathrm{RH}$ in the closed system modification. White arrows: Pit conection between wood cell wall of the fibers. Black arrows: Middle lamella.
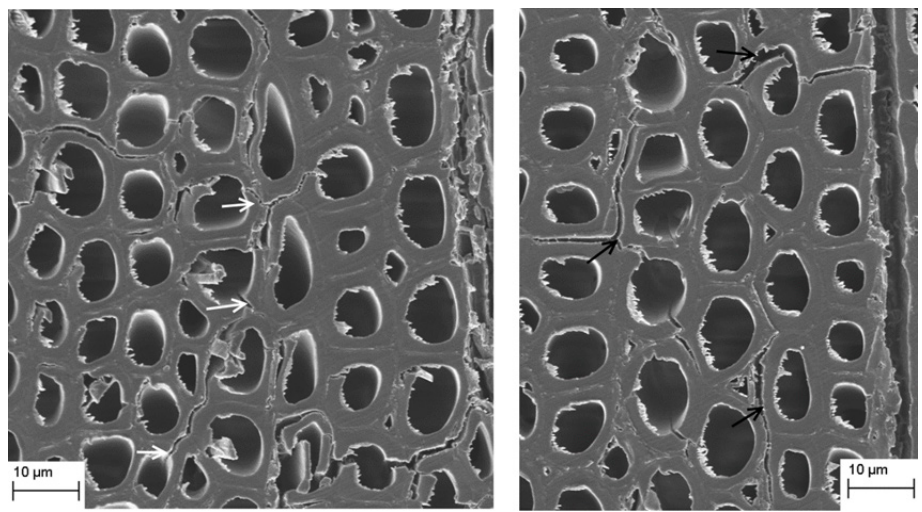

Figure 6: SEM images of thermally modified speciemens at $210^{\circ} \mathrm{C}$ in the open system modification. White arrows: Pit conection between wood cell wall of the fibers. Black arrows: Middle lamella. 


\section{CONCLUSIONS}

In general, there was not a significant influence of the process conditions on the static and dynamic mechanical properties. Closed system modification led to slightly lower static mechanical properties of wood compared to open system modifications, the inelastic deflection and inelastic work were lower in the open system, and the differences in the dynamic mechanical properties were insignificant. There were also not mayor differences at the anatomical level between open and closed systems, as both presented similar crack developments. The cracks seem to initiate at the middle lamella or pits. To further distinguish the differences between open and closed system, it would be recommended to analyse the chemical structure of the modified wood using non-destructive techniques such as Raman spectroscopy or Fourier-transform infrared spectroscopy (FTIR).

\section{REFERENCES}

Alen, R.; Kotilainen, R.; Zaman, A. 2002. Thermochemical behavior of Norway spruce (Picea abies) at 180-225 ${ }^{\circ} \mathrm{C}$. Wood Science and Technology 36 (2):163-171.

Allegretti, O.; Brunetti, M.; Cuccui, I.; Ferrari, S.; Nocetti, M.; Terziev, N. 2012. Thermo-vacuum modification of spruce (Picea abies Karst.) and fir (Abies alba mill.) wood. BioResources 7 (3):3656-3669.

Altgen, M.; Militz, H. 2016. Influence of process conditions on hygroscopicity and mechanical properties of European beech thermally modified in a high-pressure reactor system. Holzforschung 70 (10):971-979.

Altgen, M.; Willems, W.; Militz, H. 2016. Wood degradation affected by process conditions during thermal modification of European beech in a high-pressure reactor system. European Journal of Wood and Wood Products 74 (5):653-662.

Awoyemi, L.; Jones, I.P. 2011. Anatomical explanations for the changes in properties of western red cedar (Thuja plicata) wood during heat treatment. Wood Science and Technology 45 (2):261-267.

Batista, D.C.; Paes, J.B.; Bolzón-De Muñiz, G.I.; Nisgoski, S.; Da Silva- Oliveira, J.T. 2015. Microstructural aspects of thermally modified Eucalyptus grandis wood. Maderas-Cienc Tecnol 17(3):525-532.

Biziks, V.; Andersons, B.; Belkova, L.; Kapaca, E.; Militz, H. 2013. Changes in the microstructure of birch wood after hydrothermal treatment. Wood Science and Technology 47 (4):717-735.

Boonstra, M. J.; Rijsdijk, J.F.; Sander, C.; Kegel, E.; Tjeerdsma, B.; Militz, H.; Van Acker, J.; Stevens, M. 2006a. Microstructural and physical aspects of heat treated wood. Part 1. Softwoods. Maderas-Cienc Tecnol 8 (3):193-208.

Boonstra, M.J.; Rijsdijk, J.F.; Sander, C.; Kegel, E.; Tjeerdsma, B.; Militz, H.; Van Acker, J.; Stevens, M. 2006b. Microstructural and physical aspects of heat treated wood: Part 2. Hardwoods. MaderasCienc Tecnol 8 (3):209-218.

Boonstra, M.J.; Tjeerdsma, B. 2006. Chemical analysis of heat treated softwoods. Holz Als Roh-Und Werkstoff 64 (3):204-211.

Boonstra, M.J.; Van Acker, J.; Kegel, E.; Stevens, M. 2007. Optimisation of a two-stage heat treatment process: durability aspects. Wood Science and Technology 41 (1):31-57.

Borrega, M.; Kärenlampi, P. 2008. Mechanical behavior of heat-treated spruce (Picea abies) wood at constant moisture content and ambient humidity. Holz Als Roh-und Werkstoff 66 (1):63-69.

Brischke, C. 2017. Interrelationship between static and dynamic strength properties of wood and its structural integrity. Drvna Industrija 68 (1):53-60.

Brischke, C.; Rapp, A.O.; Welzbacher, C.R. 2006a. High-energy multiple impact (HEMI)-test-Part 1: A new tool for quality control of thermally modified timber. The International Research Group on Wood Preservation Document No 06-20346 IRG/WP. 
Brischke, C.; Welzbacher, C.R.; Rapp, A.O. 2006b. Detection of fungal decay by high-energy multiple impact (HEMI) testing. Holzforschung 60 (2):217-222.

Dagbro, O.; Toriainen, P.; Karlsson, O.; Morén, T. 2010. Colour responses from wood, thermally modified in superheated steam and pressurized steam atmospheres. Wood Material Science and Engineering 5 (3-4):211-219.

De Cademartori, P.H.G.; Missio, A.L.; Mattos, B.D.; Gatto, D.A. 2015. Effect of thermal treatments on technological properties of wood from two Eucalyptus species. Anais da Academia Brasileira de Ciências 87 (1):471-481.

Deutsches Institut Fur Normung. DIN. 1978. Testing of wood: bending test DIN 52186. 1978. German Institute for Standardisation, Berlin. 404.

Esteves, B.; Pereira, H. 2009. Wood modification by heat treatment: a review. BioResources 4 (1):370-

Hakkou, M.; Pétrissans, M.; Gérardin, P.; Zoulalian, A. 2006. Investigations of the reasons for fungal durability of heat-treated beech wood. Polymer Degradation and Stability 91 (2):393-397.

Hill, C.A.S. 2006. Wood Modification: Chemical, Thermal and Other Processes. John Wiley \& Sons, Ltd., West Sussex, England.

Kubojima, Y.; Okano, T.; Ohta, M. 2000. Bending strength and toughness of heat-treated wood. Journal of Wood Science 46 (1):8-15.

Lekounougou, S.; Kocaefe, D.; Oumarou, N.; Kocaefe, Y.; Poncsak, S. 2011. Effect of thermal modification on mechanical properties of Canadian white birch (Betula papyrifera). International Wood Products Journal 2(2):101-107.

Mayes, D.; Oksanen, O. 2002. ThermoWood Handbook. Finnish Thermowood Association, Helsinki, Finland.

Militz, H.; Altgen, M. 2014. Processes and properties of thermally modified wood manufactured in Europe. In: Schultz, T.P; Goodell, B; Nicholas, D.D. (eds) Deterioration and protection of sustainable biomaterials. ACS Symposium Series 1158. Oxford University Press, pp 269-285.

Phuong, L.X.; Shida, S.; Saito, Y. 2007. Effects of heat treatment on brittleness of Styrax tonkinensis wood. Journal of Wood Science 53 (3):181-186.

Poncsák, S.; Kocaefe, D.; Bouazara, M.; Pichette, A. 2006. Effect of high temperature treatment on the mechanical properties of birch (Betula papyrifera). Wood Science and Technology 40 (8):647-663.

Rapp, A.O.; Brischke, C.; Welzbacher, C.R. 2006. Interrelationship between the severity of heat treatments and sieve fractions after impact ball milling: a mechanical test for quality control of thermally modified wood. Holzforschung 60 (1):64-70.

Rautkari, L.; Hill, C.A.S. 2014. Effect of initial moisture content on the anti-swelling efficiency of thermally modified Scots pine sapwood treated in a high-pressure reactor under saturated steam. Holzforschung 68 (3):323-326.

Santos, J.A. 2000. Mechanical behaviour of Eucalyptus wood modified by heat. Wood Science and Technology 34 (1):39-43.

Sundqvist, B.; Karlsson, O.; Westermark, U. 2006. Determination of formic-acid and acetic acid concentrations formed during hydrothermal treatment of birch wood and its relation to colour, strength and hardness. Wood Science and Technology 40 (7):549.

TAPPI. 1997. Solvent extractives of wood and pulp. Test method T $204 \mathrm{~cm}-07$. Technical Association of the Pulp and Paper Industry, Atlanta, GA.

Tjeerdsma, B.F.; Boonstra, M.; Pizzi, A.; Tekely, P.; Militz, H. 1998. Characterisation of thermal151 
ly modified wood: molecular reasons for wood performance improvement. Holz Als Roh-Und Werkstoff 56 (3):149-153.

Tjeerdsma, B.F.; Militz, H. 2005. Chemical changes in hydrothermal treated wood: FTIR analysis of combined hydrothermal and dry heat-treated wood. Holz Als Roh-Und Werkstoff 63 (2):102-111.

Weigl, M.; Muller, U.; Wimmer, R.; Hansmann, C. 2012. Ammonia vs. thermally modified timber-comparison of physical and mechanical properties. European Journal of Wood and Wood Products 70 (1-3):233239.

Welzbacher, C.R.; Brischke, C.; Rapp, A.O. 2007. Influence of treatment temperature and duration on selected biological, mechanical, physical and optical properties of thermally modified timber. Wood Material Science and Engineering 2 (2):66-76.

Welzbacher, C.R.; Rassam, G.; Talaei, A.; Brischke, C. 2011. Microstructure, strength and structural integrity of heat-treated beech and spruce wood. Wood Material Science \& Engineering 6 (4):219-227.

Wentzel, M.; Altgen, M.; Militz, H. 2018a. Analyzing reversible changes in hygroscopicity of thermally modified eucalypt wood from open and closed reactor systems. Wood Science and Technology 52(4): 889-907.

Wentzel, M.; Fleckenstein, M.; Hofmann, T.; Militz, H. 2018b. Relation of chemical and mechanical properties of Eucalyptus nitens wood thermally modified in open and closed systems. Wood Material Science \& Engineering. Online first. https://www.tandfonline.com/doi/full/10.1080/17480272.2018.1450783

Willems, W. 2009. A novel economic large-scale production technology for highquality thermally modified wood. In: Engelund, F; Hill, CAS; Militz, H; Segerholm, BK (eds). Proceedings of the 4th European Conference on Wood Modification, Stockholm, Sweden. Winandy, J.E.; Lebow, P.K. 2001. Modeling strength loss in wood by chemical composition. Part I. An individual component model for southern pine. Wood and Fiber Science 33 (2):239-254.

Zaman, A.; Alen, R.; Kotilainen, R. 2000. Thermal behavior of scots pine (Pinus sylvestris) and silver birch (Betula pendula) at 200-230 ${ }^{\circ} \mathrm{C}$. Wood and Fiber Science 32 (2):138-143. 